\title{
Estimating Cost Savings for Aviation Fuel and $\mathrm{CO}_{2}$ Emission Reductions Strategies
}

\author{
Mary E. Johnson \\ Alan Gonzalez \\ Purdue University
}

\begin{abstract}
Achieving reductions in aviation greenhouse gas emissions while growing the aviation industry is both a national and a global challenge. This paper discusses and summarizes the suggestions for reducing emissions, and both the short-term and long-term emissions goals for three aviation industry groups, the European Union and United States aviation regulatory agencies, and the United Nations specialized agency for civil aviation. Reducing fuel consumption affects an air carrier's bottom line by reducing fuel costs and carbon emissions. Investments may be required in aircraft or procedural changes to reduce demand for fuel by reducing consumption while still providing the same level of air service. Investing in reducing fuel consumption is not only important to comply with any emission trading scheme, but will also become a major factor for survival in the present competitive air transportation market. A general method to estimate cost savings is developed that presents a comparison method independent of the specific type of fuel reduction method. This method uses the percentage of fuel reduced to analyze cost savings using a range of fuel prices and non-discounted payback period. Analysts may use this method for calculating the savings specific methods of reducing fuel consumption.
\end{abstract}

\section{Introduction}

The global nature of aviation is made particularly clear as aviation emissions are a global concern in today's world. The aviation industry is now part of emissions regulations affecting the European Union and it is expected to become global through the International Civil Aviation Organization (ICAO). "Sustainable development is one of the greatest challenges and opportunities facing the aviation industry in the 21st century" (European Aviation Safety Agency, 2013, para. 1). “Although the aerospace industry has already made significant efforts to reduce its environmental footprint, further technological and operational improvements are necessary to outweigh the impact of traffic growth” according to the European Aviation Safety Agency (EASA, 2013).

Aviation's role in potential effects on the environment is becoming more important due to global air traffic forecasted to grow 4 to 5\% yearly (EASA, 2013). According to IATA (International Air Transport Association, 2013), 2\% of global carbon dioxide emissions in 2012 were due to aviation. The United States Government (USG) is one government among many worldwide that is participating in global efforts to reduce emissions. "The USG has set a goal of achieving carbon neutral growth for U.S. 
commercial aviation by 2020, using 2005 emissions as a baseline” (United States Government, 2012, para. 1). "Carbon neutral growth means that aviation's net $\mathrm{CO}_{2}$ emissions stop growing, even when demand for air transport continues to grow. In other words, net $\mathrm{CO}_{2}$ emissions from aviation would peak in 2020 and would decline after that" (IATA, 2009, 4). "Between 1978 and 2011, U.S. airlines improved fuel efficiency by 120 percent, which has resulted in a savings of 3.3 billion metric tons of carbon dioxide $\left(\mathrm{CO}_{2}\right)$ savings” (Airlines for America, 2013, para. 2). In June 2013, to reach agreement before ICAO meets in early fall 2013, and to avert trade wars and a plethora of emissions trading schemes throughout the world, "airlines representing 85 percent of global traffic urged governments to adopt a single market-based system designed to offset growth in their post-2020 emissions against the funding of projects to cut emissions deemed harmful to the environment” (Reuters, 2013).

In general, the aviation industry has presented a common position consisting of three main elements: "an average improvement of $1.5 \%$ per year in terms of fuel efficiency, a carbon neutral growth from 2020 onwards, and an absolute reduction of net $\mathrm{CO}_{2}$ emissions by 50\% in 2050, compared to 2005 levels" (Fonta, 2010, p. 11). "Green House Gas (GHG) emissions trading and offsetting were introduced in 1997 as part of the Kyoto Protocol, which provided for three distinct mechanisms to regulate and control the emission goals: Emissions Trading, Clean Development Mechanism (CDM), and the Joint Implementation (JI)” (ICAO Secretariat, 2010d. p. 128). The development of these three mechanisms supported by emissions limitations and reduction commitments resulted in the establishment of the global carbon market (ICAO Secretariat, 2010d). New Zealand and the European Union are the only two active Emission Trading Systems (ETS), Japan has a voluntary national ETS and it is in the process of becoming mandatory, a U.S. ETS system is being considered at federal level, and Australia has postponed the implementation of the ETS (ICAO Secretariat, 2010b). Calculating estimates for aviation carbon emission is complex, may be accomplished by more than one method, and is based on the amount of fuel consumed by the aircraft (Johnson, Gonzalez, Kozak, \& Sperlak, 2013). Aviation ETS, carbon trading, and cap and trade are complex subjects with regard to structure of the policy, fairness and effectiveness of implementation, and nature of the economic, environmental, and political implications (Adler \& Gellman, 2012; Krammer, Dray \& Kohler, 2013; Lee et al., 2009; Meltzer, 2012; Sgouridis, Bonnefoy \& Hansman, 2011).

This paper discusses and summarizes the suggestions for reducing emissions, and both the short-term and long-term emissions goals for three aviation industry groups, the European Union and United States aviation regulatory agencies, and the United Nations specialized agency for civil aviation. Highlights of aviation related carbon emission policies are compared from the Federal Aviation Administration, EASA, ICAO, International Air Transport Association (IATA), Airlines for America (A4A), and Air Transport Action Group (ATAG). In May 2013, both ICAO and ATAG signed a joint statement on reducing aviation emissions that recognizes the need to stabilize carbon dioxide emissions in times of increasing demand for aviation and to improve fuel 
efficiency by innovating and adopting best practices and technologies (ICAO, 2013a). Reducing fuel consumption affects an air carrier's bottom line by reducing fuel costs and, if the consumption of fuel and emission of carbon results in a cost for carbon such as under an ETS, then carbon emissions costs. Investments may be required in aircraft or procedural changes to reduce demand for fuel by reducing consumption while still providing the same level of air service. Investing in reducing fuel consumption is not only important to comply with any emission trading scheme or reducing emissions for altruistic reasons, but will also become a major factor for survival in the present competitive air transportation market. A general method to estimate cost savings is developed that presents a comparison method independent of the specific type of fuel reduction method. This method uses the percentage of fuel reduced to analyze cost savings using a range of fuel prices and non-discounted payback period.

\section{Literature Review}

A literature review of carbon emission information from a total of six governmental and industry groups was conducted. This section discusses the published viewpoints of ICAO, FAA, IATA, EASA, A4A, and ATAG with regard to aviation carbon emissions.

\section{International Civil Aviation Organization}

The International Civil Aviation Organization (ICAO) is a United Nations agency that is responsible for the development of international civil aviation. "In 2004, ICAO adopted three major environmental goals, to: limit or reduce the number of people affected by significant aircraft noise; limit or reduce the impact of aviation emissions on local air quality; and limit or reduce the impact of aviation greenhouse gas emissions on the global climate" (ICAO, 2013b, para. 2). Two important key elements from the 36th and 37th ICAO Assemblies are the goals of improving fuel efficiency by $2 \%$ per year until 2050, and stabilizing carbon dioxide emissions at the 2020 level (Hupe, 2010). The Group on International Aviation and Climate Change (GIACC), a sector of ICAO, works under the United Nations Framework Convention on Climate Change (UNFCC) and the Kyoto Protocol to achieve these goals (Hupe, 2010). The Committee on Aviation Environmental Protection (CAEP) is a technical committee of the ICAO Council, responsible for conducting studies and recommending measures to minimize and reduce aviation's impact on the environment, including setting certification standards for aircraft noise and aircraft engine emissions (Hupe, 2010).

ICAO predicts 4.8\% passenger traffic per year through the year 2036; although noise, emissions, and fuel consumption prediction is less than 4.8\% (ICAO Secretariat, 2010). In 2006, 187 million metric tons (MT) of fuel was consumed globally (ICAO Secretariat, 2010). Approximately 62\% of global aviation fuel consumption is from international flights (ICAO Secretariat, 2010). Meanwhile, it is expected that global aircraft fuel consumption will increase between 3\% and 3.5\% per year (ICAO Secretariat, 2010). 
"Environmental standards set by ICAO and the investments in technology and improved operational procedures are allowing aviation's noise, local air quality, and $\mathrm{CO}_{2}$ footprints to grow at a rate slower than the demand for air travel" (ICAO Secretariat, 2010, p. 18). Cooperation between ICAO and the UN's Intergovernmental Panel on Climate Change (IPCC), “is key to obtain a better scientific understanding of aviation's impact on the global climate” (ICAO Secretariat, 2010, p. 31).

"The ultimate objective of the United Nations Framework Convention on Climate Change (UNFCCC) is to achieve stabilization of greenhouse gas concentrations in the atmosphere at a level that would prevent an irreversible change in the global climate system” (ICAO Secretariat, 2010, p. 33). According to the Intergovernmental Panel on Climate Change (IPCC), "climate change refers to any change in climate over time, whether due to natural variability, or as a result of human activity" (IPCC, 2007, para. 2). According to the IPCC, "global climate change is caused by the accumulation of greenhouse gases (GHG) in the lower atmosphere... the GHG of most concern is carbon dioxide $\left(\mathrm{CO}_{2}\right)$ ” (ICAO Secretariat, 2010a, p. 38).

Aircraft engines produce emissions that are “...released directly into the upper troposphere and lower stratospheres where they are believed to have a different impact on atmospheric composition than emissions at lower altitudes...” (ICAO Secretariat, 2010a, p.38). Engine combustion of jet fuel and aviation gasoline produces emissions with approximately $70 \%$ carbon dioxide $\left(\mathrm{CO}_{2}\right), 30 \%$ water vapor, and $1 \%$ of other emissions (ICAO Secretariat, 2010). $\mathrm{CO}_{2}$ and water vapor are greenhouse gases (GHG) (ICAO Secretariat, 2010). Aviation emissions of $\mathrm{CO}_{2}$ emissions are expected to increase $3 \%$ to 4\% annually (ICAO Secretariat, 2010). Aviation also emits nitrogen oxides (NOx), sulfur oxides (SOx), hydrocarbons (HC), and black carbon (BC) particulate matter (ICAO Secretariat, 2010a). Since 2008, ICAO provided a Carbon Emissions Calculator on their website and mobile application that uses a methodology developed by CAEP. The calculator methodology also uses aircraft types, route data, passenger load factors, cargo, and other data provided by the airline industry (ICAO Secretariat, 2010a).

IPCC issued guidelines to assist countries in developing GHG national inventories, including GHG from aviation (ICAO Secretariat, 2010a). “The 2006 IPCC guidelines suggest collecting the fuel consumption for domestic and international aviation by surveying airline companies or estimating it from aircraft movement data and standard tables of fuel consumed, or both” (ICAO Secretariat, 2010a, p. 40). ICAO’s Fuel Efficiency Rules of Thumb are stated as:

- On average, an aircraft will burn about $0.03 \mathrm{~kg}$ of fuel for each $\mathrm{kg}$ carried per hour. This number will be slightly higher for shorter flights and for older aircraft and slightly lower for longer flights and newer aircraft.

- The total commercial fleet combined flies about 57 million hours per year; so, saving one kg on each commercial flight could save roughly 170,000 tonnes of fuel and 540,000 tonnes of CO2 per year. 
- Reducing the weight of an aircraft, for example by replacing metal components with composites, could reduce fuel burn by as much as $5 \%$.

- Average fuel burn per minute of flight: $49 \mathrm{~kg}$.

- Average of fuel burn per nautical mile (NM) of flight: $11 \mathrm{~kg}$. (ICAO Secretariat, 2010a, p. 41)

According to ICAO, aircraft designed after 2010 should be $15 \%$ more fuel efficient and release $40 \%$ lower emissions than comparable aircraft designed earlier (ICAO Secretariat, 2010b). Improvements in aircraft technology have had the most impact on increasing fuel efficiency, but there are additional gains possible through improved operations, air traffic control and aircraft efficiency (ICAO Secretariat, 2010b).

"Historic trends in improving efficiency levels show that aircraft entering today's fleet are around 80\% more fuel efficient than they were in the 1960's” (Fonta, 2010, p. 72). In order to improve aircraft performance it is needed to reduce aircraft weight, improve airplane aerodynamics to reduce drag, improve engine performance to reduce fuel burn (Fonta, 2010). "Friction drag is the area which currently promises to be one of the largest areas of potential improvement in aircraft aerodynamic efficiency over the next 10 to 20 years" (Fonta, 2010, p.74). In order for air traffic improvements to be realized, an interoperable global air traffic management (ATM) system that can be used by all users during all phases of flight is necessary (ICAO Secretariat, 2010c). Examples of other national and regional systems with goals of improving flight operations and reducing emissions include NextGen from the FAA, Single European Sky ATM Research (SESAR) from the European Union, the Atlantic Interoperability Initiative to Reduce Emissions (AIRE) a partnership between the FAA and the European Commission, and the Asian Pacific Initiative to Reduce Emissions (ASPIRE) an agreement between Airservices Australia, Airways New Zealand, the FAA, Japan Civil Aviation Bureau, and the Civil Aviation Authority of Singapore. All these programs have the same objective of improving flight operations and reduce emissions (ICAO Secretariat, 2010c).

Currently, the offset of aviation emissions is a voluntary system addressing passengers and not cargo, non-revenue passengers and repositioning flights (Kråkenes \& Keldusild, 2010). ICAO's Committee on Aviation Environmental Protection (CAEP) received 50 voluntary replies from 24 States and regions including 37 airlines; Boeing was the only US company that replied. (Shimizu, 2010). More than 30 IATA member airlines offer voluntary carbon offsets to passengers. The carbon offset program gives passengers the option to purchase carbon credits to offset emissions from booked flights (Steele, 2010). In this IATA program, carbon credits are generated by projects with Certified Emission Reductions (CERs) issued through the Clean Development Mechanism (CDM) and approved under the United Nations Framework Convention for Climate Change (Steele, 2010). Passengers may pay for projects by estimating the carbon credits per passenger using the ICAO Carbon Emissions Calculator and may select one project from a maximum of three projects offered by the airline (Steele, 2010). 


\section{Federal Aviation Administration}

The Federal Aviation Administration (FAA) is the US agency that regulates and oversees commercial aviation. The FAA sustainability's goal for the future is "To develop and operate an aviation system that reduces aviation's environmental and energy impacts to a level that does not constrain growth and is a model for sustainability" (Federal Aviation Administration, 2012b, p. 9). The United States Government (USG) has committed to addressing the climate change impacts of commercial aviation by using multiple approaches to achieve commercial aviation carbon neutral growth by 2020, a reduction of 115 million metric tons of carbon dioxide emissions from the 2005 baseline (United States Government, 2012).

The FAA identified the following areas for improvement to reduce $\mathrm{CO}_{2}$ emissions from aviation: aircraft and engine technology, operational, alternative fuels development and distribution, policies, standards, measures, scientific understanding, and modeling analysis (United States Government, 2012). The biggest contributor to carbon neutral growth is expected to be aircraft technology and operational innovations, with an estimated reduction of $47 \mathrm{MT}$ of $\mathrm{CO}_{2}$ by 2020 (United States Government, 2012). $\mathrm{CO}_{2}$ reductions from alternative fuels are uncertain, but could be as high as $34 \mathrm{MT}$ of $\mathrm{CO}_{2}$ (United States Government, 2012).

The FAA released the Aviation Environmental Design Tool (AEDT2a) in 2012, to measure and evaluate how new aircraft technologies, operations, and alternative fuels, will impact noise, emissions and fuel burn (Federal Aviation Administration, 2012a). The U.S. positions on $\mathrm{CO}_{2}$ standard, operational measures, and alternative fuels were previously accepted at ICAO assemblies (Federal Aviation Administration, 2012a). The FAA will continue cooperation with key aviation countries and stakeholders to enforce a global ETS standard through ICAO (Federal Aviation Administration, 2012a). The FAA is focused on reducing noise and emission impacts of aviation through supporting new technologies, sustainable alternative fuels research, and innovations (Federal Aviation Administration, 2012b).

Programs such as The Continuous Lower Energy, Emissions, and Noise (CLEEN) launched by the FAA and NASA's Environmentally Responsible Aviation (ERA) focus on engine technology and aircraft structures that will benefit the commercial industry (United States Government, 2012). CLEEN's goal is to develop and demonstrate, by 2015, technology that will reduce fuel burn by 33 percent. ERA's goal is to reduce mission fuel burn by 50 percent before 2020 for passenger and cargo transport aircraft (United States Government, 2012).

CLEEN is one part of NextGen, a multi-agency redesign of the National Airspace System to dramatically increase the efficiency of aircraft operations and reduce GHG emissions (United States Government, 2012). The FAA implementation of NextGen is intended to support the overall goal of carbon neutral growth by reducing 1.4 billion 
gallons jet fuel consumption that contributes $14 \mathrm{MT}$ of carbon dioxide (United States Government, 2012).

\section{International Air Transport Association}

The International Air Transport Association (IATA), an industry trade association that represents, leads, and serves more than 200 international airlines. IATA's goal on emissions is as follows "Our industry has a vision to achieve carbon neutral growth on the way to a carbon free industry. The strategy for this is based on four pillars: technological progress, operational measures, infrastructure improvements and economic instruments" (IATA, 2013). According to IATA, "Fuel efficiency improved by 16\% between 2001 and 2011. An additional efficiency gain of $17 \%$ is expected between by 2020" (IATA, 2013, para. 5). "It is estimated that up to $8 \%$ of all jet fuel is wasted as a result of inefficient routes” (IATA, 2013, para 7).

According to IATA, a strong commitment from aviation system components such as airlines, fuel companies, airports, and regulators is required to achieve carbon neutral growth which may be reached through either aviation emissions reductions or offsetting aviation emissions with emissions reductions in other industries (IATA, 2009). IATA asserts that airlines must have the capacity to invest in emissions mitigation measures for carbon neutral growth to work (IATA, 2009). Investments in retrofits, production updates, and new aircraft designs are expected to reduce emissions $7 \%$ to $13 \%, 7 \%$ to $18 \%$, and $25 \%$ to $50 \%$, respectively (IATA, 2009).

Technology improvements such as aircraft and engine designs, lighter and stronger materials, and biofuel are projected to reduce aviation emissions by $20 \%$ to $35 \%$ are identified on IATA's Technology Roadmap (IATA, 2009). IATA estimates that by 2020, airlines will spend $\$ 1.5$ trillion on about 5,500 aircraft to replace $27 \%$ of the total fleet resulting in a $21 \%$ reduction in $\mathrm{CO}_{2}$ emissions (IATA, 2009). For example, retrofits such as winglets and drag reduction could reduce emissions by $1 \%$ by 2020 if $\$ 2$ billion are invested; and sustainable biofuels could reduce $\mathrm{CO}_{2}$ emissions by $80 \%$ over the entire lifecycle (IATA, 2009).

To reduce the 6\% inefficiency identified by IPCC in 1999, IATA formed teams of experts in 2005 to make recommendations to airlines on fuels and emissions savings such as reducing use of auxiliary power units and improved flight procedures, (IATA, 2009). IATA projects that these teams will reduce emissions by $3 \%$ by 2020 , and estimates that 11 MT of $\mathrm{CO}_{2}$ was saved in 2008 (IATA, 2009). Inefficiencies in air transport infrastructure were reduced from $12 \%$ in 1999 to $4 \%$ according to IPCC estimates (IATA, 2009). An investment of \$58 billion for more efficient Air Traffic Management systems, such as SESAR, and airport infrastructure are expected to reduce emissions by 4\% by 2020 (IATA, 2009). 
Airspace improvements such as Performance-Based Navigation (PBN) and Continuous Descent Arrival (CDA) will play major roles on reducing $\mathrm{CO}_{2}$ emissions (IATA, 2009). "Using CDA rather than the traditional stepped approach methods for landing can save up to $630 \mathrm{~kg}$ of $\mathrm{CO}_{2}$ per landing” (IATA, 2009, no page number). IATA calculated that in 2025, a yearly amount of 90 million metric tons of $\mathrm{CO}_{2}$ will need to be reduced in order to maintain 2020 levels and will require $\$ 7$ billion per year in investments (IATA, 2009). IATA estimates that in order to achieve carbon-neutral growth from 2020 onward, airlines will have to invest approximately \$1.6 trillion (IATA, 2009).

\section{European Aviation Safety Agency}

The European Aviation Safety Agency (EASA) is the European Union agency that regulates and oversees commercial aviation safety. EASA has the following view on emissions: "Europe's Flight path 2050 officially supports the Air Transport Action Group (ATAG) target of reaching carbon-neutral growth in 2020 and reducing aviation's overall $\mathrm{CO}_{2}$ emissions by half between 2005 and 2050” (EASA, 2013, para. 1).

Many governments around the world are working through the United Nations Framework Convention on Climate Change (UNFCCC) and the International Civil Aviation Organization (ICAO) to reduce climate change due to aviation while growing aviation (EASA, 2013). While the Kyoto Protocol excludes international aviation, aviation traffic is expected to increase $4 \%$ to $5 \%$ annually and is expected to contribute significantly to global warming by 2050 due to this growth and reductions in global warming in other industries due to energy efficient technologies (EASA, 2013).

According to EASA, the inclusion of aviation in the EU Emissions Trading Scheme (ETS) is an essential to meet carbon neutral growth goals (EASA, 2013). A major obstacle to aviation biofuels is the existence of a reliable and cost effective supply for commercial aviation (EASA, 2013). EASA states that "The ultimate aim for the industry must be sustainable development, where the environment is not sacrificed for growth and future generations will be able to continue to benefit from air travel” (EASA, 2013, para. 8).

\section{Airlines for America}

Airlines for America (A4A) is a US trade organization that sponsors airlines growth and well-being (A4A, n.d.) A4A supports a global approach under ICAO to aviation climate change policy, and technological advances throughout the aviation system (A4A, n.d.). A4A was a co-founder of the Commercial Aviation Alternative Fuels Initiative (CAAFI) in 2006 and remains an active member. A4A member airlines are actively looking for methods to reduce aircraft emissions through new aircraft, alternative fuels, and operational performance. 


\section{Air Transport Action Group}

The Air Transport Action Group (ATAG) is composed of aviation industry experts that focus on aviation sustainability. ATAG guided a group of aviation leaders so that aviation became "the first industry to have a long-term plan to tackle its climate change impacts” (ATAG, 2013, para. 2). In 2009, the ATAG Board developed three environmental goals that IATA agreed to follow: $1.5 \%$ yearly improvement in fuel efficiency from 2009-2020, carbon neutral growth from 2020, and 50\% reduction in net aviation emissions by 2050 with a 2005 baseline (ATAG, 2013). These targets have also influenced ICAO and the United Nations Framework Convention on Climate Change (UNFCCC) (ATAG, 2013). ATAG (2012) identifies four recommendations for future climate change agreements:

1. Post-2020 global climate agreements should include aircraft $\mathrm{CO}_{2}$ emissions coordinated through ICAO.

2. ICAO should adopt a global aviation emissions approach that does not affect fair competition and does treat aviation as a sector, not by country.

3. A global aviation emissions inventory should reliably track actual emissions versus targets, and avoid double counting and using each credit more than once.

4. Using the 2005 baseline levels, carbon neutral aviation growth beginning in 2020 and 50\% lower emissions in 2050 is possible through improving air traffic management, aircraft and operations improvements, biofuels, and a multilateral market-based aviation emissions system.

Other recommendations include ICAO to develop emission (including GHG, noise, and local air quality) mitigation measures allowing carriers to decide what measures to use to meet their $\mathrm{CO}_{2}$ targets; carriers prioritize reinvestment of revenues on cost effective measures to reduce emissions; administration and implementation should be taken by both government and industry; and special needs should be taken into consideration for developing countries (ATAG, 2012). In order to achieve all these recommendations governments should be involved in the modernization of air traffic management, fleet and operations technology improvements through academic and companies, availability of biofuels for aviation, and development of multilateral markets for global aviation emissions (ATAG, 2012). ATAG recommends global multilateral measures coordinated through ICAO and comments on the use of unilateral measures as "It also puts aviation at risk of being caught in a web of uncoordinated, costly and ineffective measures and countermeasures imposed by governments, which will benefit no one but may harm economies and environments worldwide” (ATAG, 2012, p 4). 


\section{Summary of Aviation Organization Carbon Emissions Viewpoints}

In summary, examination of the carbon emissions discussion of the aviation bodies associated with the UN, US, EU, and airlines reveals that there are similarities and differences in suggested methods to reduce fuel consumption and in environmental targets. Table 1 highlights the suggested methods for reducing fuel consumption for the six agencies in this study. There are similarities at the high level in the suggestions of technological improvements, operations improvements, and alternative fuels. Differences are noted in the contrasts between the ICAO market based measures and the IATA positive economic measures. The FAA suggests scientific understanding, modeling and analysis. Table 1 identifies the high level suggestions and shows that there is consensus on many methods, but there are differences across the agencies.

Similarly, in Table 2, the short-term and long-term emissions targets are summarized for the six agencies in this study. The comparison of baseline years used by the agencies is important for consistent measurements of progress toward the emissions targets. Table 1 identifies the high level targets and shows that there is consensus on many measures, but there are differences_across the agencies in timelines and percentages. For instance, EASA, IATA, A4A and ATAG are in alignment with each other on long-term goals. In contrast, ICAO expresses the long-term goal in terms of a percent reduction per year and the FAA's long-term goal in terms of a specific amount emission reduction.

\section{Methodology}

In search of a more general method to estimate cost savings, the authors developed a comparison method that is independent of the specific type of fuel reduction method. This method uses the percentage of fuel reduced to analyze cost savings. Analysts may use this method for specific routes or groupings of routes of interest. For convenience, this method is illustrated using 5,000 and 10,000 gallons of fuel consumed per flight and specific fuel consumption reduction percentages of 3\%, $4 \%$ and $5 \%$. Payback period is calculated by determining the number of roundtrip flights required to payback a $\$ 1$ million dollar investment. This method may be adapted to the needs of specific analyses by changing the fuel consumption or the fuel reduction percentages to match a specific investment.

The primary limitations of this method are that it does not predict future costs for fuel or carbon; it does not identify capital expenditures such as aircraft modifications or fleet changes, nor non-capital expenses such as equipment changes, ground costs for adding a stop, any adverse maintenance events; it considers all ETS costs as those costs above any free allowances, and it does not include time value of money, tax, or financing considerations. 
Table 1

Suggested Methods to Reduce Fuel Consumption

\begin{tabular}{|c|c|c|c|c|c|}
\hline $\mathrm{ICAO}^{\mathrm{a}}$ & FAA $^{b}$ & EASA $^{\mathrm{c}}$ & IATA $^{d}$ & $\mathrm{~A} 4 \mathrm{~A}^{\mathrm{e}}$ & ATAG $^{\mathrm{f}}$ \\
\hline $\begin{array}{l}\text { Green aircraft } \\
\text { technologies }\end{array}$ & $\begin{array}{l}\text { Aircraft/engine } \\
\text { technology } \\
\text { improvement }\end{array}$ & $\begin{array}{l}\text { Technological } \\
\text { improvements }\end{array}$ & $\begin{array}{l}\text { Improved } \\
\text { technology }\end{array}$ & $\begin{array}{l}\text { Fuel efficient } \\
\text { aircraft }\end{array}$ & $\begin{array}{l}\text { Aircraft } \\
\text { modifications }\end{array}$ \\
\hline $\begin{array}{l}\text { Operational } \\
\text { measures }\end{array}$ & $\begin{array}{l}\text { Operational } \\
\text { improvements }\end{array}$ & $\begin{array}{l}\text { Operational } \\
\text { improvements }\end{array}$ & $\begin{array}{l}\text { Effective } \\
\text { operations }\end{array}$ & $\begin{array}{l}\text { Operational } \\
\text { performance }\end{array}$ & $\begin{array}{l}\text { Operational } \\
\text { improvements }\end{array}$ \\
\hline $\begin{array}{l}\text { Alternative } \\
\text { fuels for } \\
\text { aviation }\end{array}$ & $\begin{array}{l}\text { Alternative fuels } \\
\text { development and } \\
\text { deployment }\end{array}$ & $\begin{array}{l}\text { Alternative } \\
\text { fuels }\end{array}$ & $\begin{array}{l}\text { Sustainable } \\
\text { biofuels }\end{array}$ & $\begin{array}{l}\text { Alternative } \\
\text { fuels }\end{array}$ & $\begin{array}{l}\text { Sustainable } \\
\text { alternative fuels }\end{array}$ \\
\hline \multirow[t]{3}{*}{$\begin{array}{l}\text { Market based } \\
\text { measures }\end{array}$} & $\begin{array}{l}\text { Policies, standards } \\
\text { and measures }\end{array}$ & & $\begin{array}{l}\text { Positive } \\
\text { economic } \\
\text { measures }\end{array}$ & & $\begin{array}{l}\text { Carbon } \\
\text { markets/economic } \\
\text { measures }\end{array}$ \\
\hline & $\begin{array}{l}\text { Scientific } \\
\text { understanding } \\
\text { modeling/analysis }\end{array}$ & & $\begin{array}{l}\text { Efficient } \\
\text { infrastructure }\end{array}$ & & New technologies \\
\hline & & & & & $\begin{array}{l}\text { Special needs for } \\
\text { developing } \\
\text { countries }\end{array}$ \\
\hline
\end{tabular}

Note. ${ }^{\mathrm{a}}$ (ICAO, 2010f). ${ }^{\mathrm{b}}$ (USG, 2012)(FAA, 2012). ${ }^{\mathrm{c}}$ (EASA, 2013). ${ }^{\mathrm{d}}$ (IATA, 2009)(IATA, 2013). ${ }^{\mathrm{e}}(\mathrm{A} 4 \mathrm{~A}, 2013)$. f(ATAG, 2012)(ATAG, 2013). 
Table 2

Environmental Targets by Aviation Agencies

\begin{tabular}{|c|c|c|c|}
\hline Agency & Short Term Target & Baseline Year & Long Term Target \\
\hline $\mathrm{ICAO}^{\mathrm{a}}$ & $\mathrm{CO}_{2}$ stabilized at 2020 levels. & 2020 & $\begin{array}{l}2 \% \text { fuel efficiency up to year } \\
2050 .\end{array}$ \\
\hline FAA $^{b}$ & $\begin{array}{l}\mathrm{CO}_{2} \text { stabilized at } 2005 \text { levels thru } 2020 \text {. } \\
\text { One billion gallons of renewable } \\
\text { jet fuel is used by aviation by } 2018 \text {. } \\
2 \% \text { fuel efficiency per year. }\end{array}$ & 2005 & $\begin{array}{l}\text { Further } 60 \text { MT reduction by } \\
2026 \text { 2\% annual fuel efficiency. }\end{array}$ \\
\hline EASA $^{\mathrm{c}}$ & $\begin{array}{l}1.5 \% \text { fuel efficiency per year } \\
\text { from } 2009 \text { to } 2020 \text {. } \\
\mathrm{CO}_{2} \text { stabilized at } 2020 \text { levels. }\end{array}$ & 2005 and 2020 & $\begin{array}{l}\text { 50\% less emission by } 2050 \\
\text { compared to } 2005 \text { levels. }\end{array}$ \\
\hline IATA $^{d}$ & $\begin{array}{l}1.5 \% \text { fuel efficiency per year from } 2009 \\
\text { to } 2020 . \mathrm{CO}_{2} \text { stabilized at } 2020 \text { levels. }\end{array}$ & 2005 and 2020 & $\begin{array}{l}\text { 50\% less emission by } 2050 \\
\text { compared to } 2005 \text { levels. }\end{array}$ \\
\hline $\mathrm{A} 4 \mathrm{~A}^{\mathrm{e}}$ & $\begin{array}{l}1.5 \% \text { fuel efficiency per year through } \\
2020 \text {. }\end{array}$ & 2005 & $\begin{array}{l}50 \% \text { less emission by } 2050 \\
\text { compared to } 2005 \text { levels. }\end{array}$ \\
\hline $\operatorname{ATAG}^{\mathrm{f}}$ & $\begin{array}{l}1.5 \% \text { fuel efficiency per year from } 2009 \\
\text { to } 2020 . \mathrm{CO}_{2} \text { stabilized at } 2020 \text { levels. }\end{array}$ & 2005 and 2020 & $\begin{array}{l}50 \% \text { less emission by } 2050 \\
\text { compared to } 2005 \text { levels. }\end{array}$ \\
\hline
\end{tabular}

Note. ${ }^{\mathrm{a}}$ (ICAO, 2010f). ${ }^{\mathrm{b}}$ (USG, 2012)(FAA, 2012)(FAA, 2012a). ${ }^{\mathrm{c}}(\mathrm{EASA}, 2013) .{ }^{\mathrm{d}}\left(\right.$ IATA, 2009)(IATA, 2013). ${ }^{\mathrm{e}}(\mathrm{A} 4 \mathrm{~A}, 2013)$.

f(ATAG, 2012)(ATAG, 2013).

\section{Results and Discussion}

A baseline analysis of the ETS costs and fuel costs for a trip in or out of an EU airport that requires 5,000 or 10,000 gallons of jet fuel is shown in Table 3. Fuel consumed by flight is converted into equivalent carbon credits. Both the fuel cost and the emissions costs are based on the consumption of 5,000 and 10,000 gallons of jet fuel. To estimate the total amount of $\mathrm{CO}_{2}$ emissions in metric tons, the gallons of fuel must be converted into metric tons using the EPA Emission factor for Jet Fuel of 00975. To calculate the total allowance cost, multiply the $\mathrm{CO}_{2}$ metric tons by the allowance price. Using the carbon credit price of $\$ 5.44$, the emissions costs would be $\$ 265$ and $\$ 530$ respectively. 
Table 3

Emissions Cost Analysis

Jet Fuel

Consumption

Total Emission of

ETS Allowance

$\mathrm{CO}_{2} \mathrm{Eq} \quad$ Price $^{\mathrm{b}}$

Allowance Cost

5,000 Gallons

0.00975

48.75

$\$ 5.44$

$\$ 265$

10,000 Gallons

0.00975

97.50

$\$ 5.44$

$\$ 530$

Note: ${ }^{\mathrm{a}}$ Environmental Protection Agency (2013) Metric tons of $\mathrm{CO}_{2}$ Eq per gallon. ${ }^{\mathrm{b}}$ Intercontinental Exchange (2013) Allowance price $€ 4.19$ per Metric ton as of March 22, 2013. Total Emission of $\mathrm{CO}_{2}$ in metric tons. ETS Allowance Price and costs in U.S. Dollars. Currency exchange from Euro to U.S. Dollar 1.298 from Yahoo! Finance (2013).

Tables 4 and 5 show the total costs of jet fuel and allowances from flights consuming 5,000 and 10,000 gallons. In these tables, calculations were conducted using fuel prices ranging from $\$ 2.00 /$ gal to $\$ 4.00 /$ gal to provide estimates when fuel prices are not tied to specific years.

Table 4

Round Trip Cost Including 5,000 Gallons of Jet Fuel and Allowances

$\begin{array}{lll}\text { Jet Fuel Price per Gallon } & \text { a } & \text { Total Jet Fuel Cost } \quad \text { Total Round Trip Cost }\end{array}$

\begin{tabular}{lll}
\hline$\$ 2.00$ & $\$ 10,000$ & $\$ 10,265$ \\
$\$ 2.50$ & $\$ 12,500$ & $\$ 12,765$ \\
$\$ 3.00$ & $\$ 15,000$ & $\$ 15,265$ \\
$\$ 3.50$ & $\$ 17,500$ & $\$ 17,765$ \\
$\$ 4.00$ & $\$ 20,000$ & $\$ 20,265$ \\
\hline
\end{tabular}

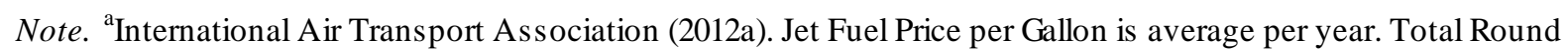
Trip Cost includes Allowance and Gasoline Expenses. 
Table 5

Round Trip Cost Including 10,000 Gallons of Jet Fuel and Allowances

Jet Fuel Price per Gallon ${ }^{\mathrm{a}}$

Total Jet Fuel Cost

Total Round Trip Cost

$\$ 2.00$

$\$ 20,000$

$\$ 20,530$

$\$ 2.50$

$\$ 25,000$

$\$ 25,530$

$\$ 3.00$

$\$ 30,000$

$\$ 30,530$

$\$ 3.50$

$\$ 35,000$

$\$ 35,530$

$\$ 4.00$

$\$ 40,000$

$\$ 40,530$

Note. ${ }^{\text {a}}$ International Air Transport Association (2012a). Jet Fuel Price per Gallon is average per year. Total Round Trip Cost includes Allowance and Gasoline Expenses.

Once the baseline is established, possible improvements may be considered that reduce fuel consumption and therefore, fuel costs and emissions costs. The cost of the improvement is then compared to the cost savings generated. In this example, the authors selected a \$1 million investment. The investment is not required to be a capital investment such as an aircraft modification nor an added expense such as a flight operation change. This method is independent of the particular improvement because the method only considers the impact of reducing fuel consumption and not the implications from the specific method. For example, a capital investment to modify the wings or fuselage may also include tax, time value of money and depreciation. Table 6 demonstrates the cost reduction and number of roundtrips needed to payback for a $\$ 1$ million investment to reduce fuel consumption by 3, 4 and 5 percent. This payback period is non-discounted meaning that the time value of money is not considered. Decisionmaking personnel need to include the time value of money for their company which is specific to each company. 
Table 6

One Million US Dollars Investment to Reduce Fuel Consumption Analysis Using 10,000 gallons per Roundtrip Flight

\begin{tabular}{|c|c|c|c|c|c|}
\hline Fuel Price & $\$ 2.00$ & $\$ 2.50$ & $\$ 3.00$ & $\$ 3.50$ & $\$ 4.00$ \\
\hline Total Trip Cost & $\$ 20,530$ & $\$ 25,530$ & $\$ 30,530$ & $\$ 35,530$ & $\$ 40,530$ \\
\hline Fuel Reduction & $3 \%$ & $3 \%$ & $3 \%$ & $3 \%$ & $3 \%$ \\
\hline Savings & $\$ 616$ & $\$ 766$ & $\$ 916$ & $\$ 1,066$ & $\$ 1,216$ \\
\hline Roundtrips to Payback & 1,624 & 1,306 & 1,092 & 938 & 822 \\
\hline Payback in Years & 1.1 & 0.9 & 0.7 & 0.6 & 0.6 \\
\hline Total Trip Cost & $\$ 20,530$ & $\$ 25,530$ & $\$ 30,530$ & $\$ 35,530$ & $\$ 40,530$ \\
\hline Fuel Reduction & $4 \%$ & $4 \%$ & $4 \%$ & $4 \%$ & $4 \%$ \\
\hline Savings & $\$ 821$ & $\$ 1,021$ & $\$ 1,221$ & $\$ 1,421$ & $\$ 1,621$ \\
\hline Roundtrips to Payback & 1,218 & 979 & 819 & 704 & 617 \\
\hline Payback in Years & 0.8 & 0.7 & 0.6 & 0.5 & 0.4 \\
\hline Total Trip Cost & $\$ 20,530$ & $\$ 25,530$ & $\$ 30,530$ & $\$ 35,530$ & $\$ 40,530$ \\
\hline Fuel Reduction & $5 \%$ & $5 \%$ & $5 \%$ & $5 \%$ & $5 \%$ \\
\hline Savings & $\$ 1,027$ & $\$ 1,277$ & $\$ 1,527$ & $\$ 1,777$ & $\$ 2,027$ \\
\hline Roundtrips to Payback & 974 & 783 & 655 & 563 & 493 \\
\hline Payback in Years & 0.7 & 0.5 & 0.4 & 0.4 & 0.3 \\
\hline
\end{tabular}

Note. Payback in years is calculated using an average of round trips per year estimate of 1,460 . Payback is calculated using savings.

The fuel costs per gallon range from $\$ 2.00$ /gallon to $\$ 4.00 /$ gallon. For example at $\$ 3.00$ /gallon, it would take 1,110 roundtrips to payback a $\$ 1$ million investment that reduces fuel consumption by $4 \%$. The more expensive the fuel is per gallon, the fewer trips required to pay back the $\$ 1$ million. To illustrate this, compare the 1,054 roundtrips needed at $\$ 2.00 /$ gallon versus the 1,085 at $\$ 4.00 /$ gallon. Payback is also calculated in 
years, this was done by assuming there are 4 daily trips per day on a 365 day year. For example using roundtrips to payback of 1,645 over the assumed 1,460 round trips per year equals 1.1 years for payback. Figure 1 presents the payback in years for fuel prices ranging from $\$ 2.00$ to $\$ 4.00$ for 3\%, $4 \%$, and 5\% reduction in fuel consumption.

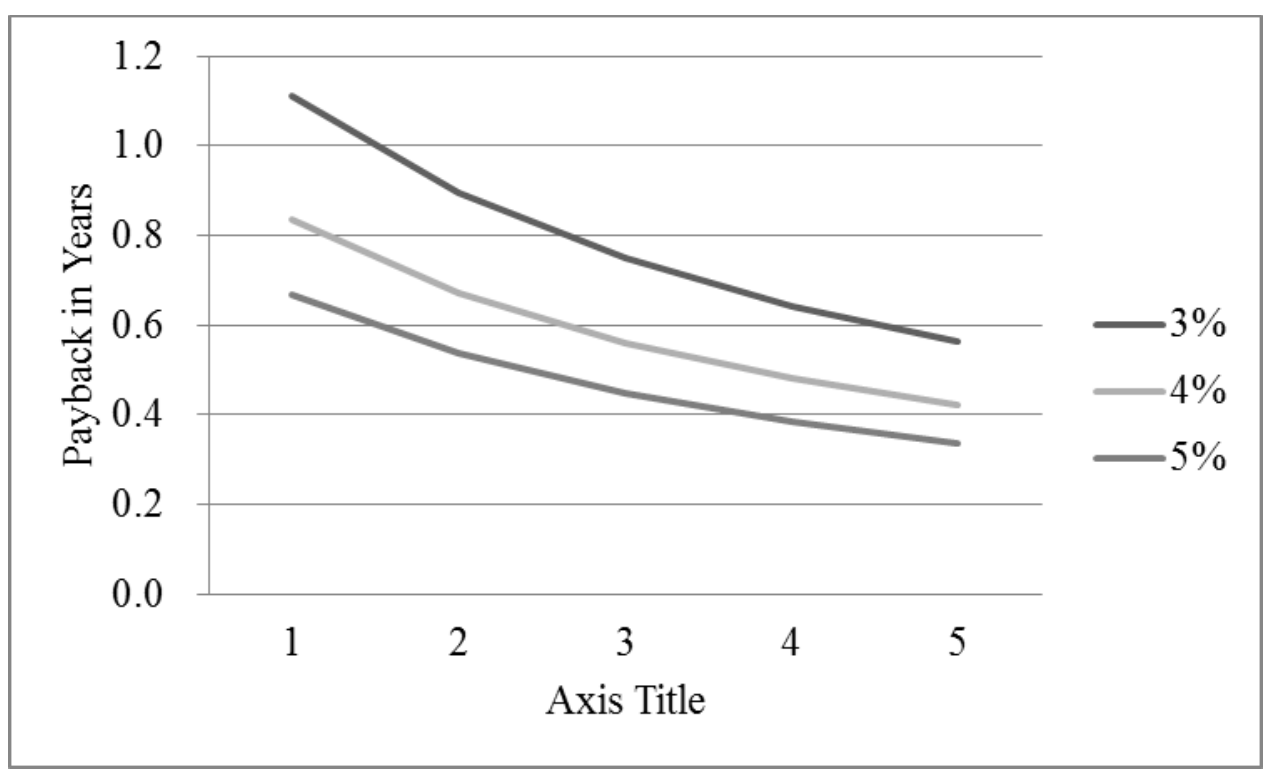

Figure 1. Comparison of payback using a range of fuel prices.

The jet fuel prices shown in Table 7 and 8 are average price per gallon for each year from 2008 to 2012 (U.S. Energy Information Administration, 2013). The jet fuel costs are calculated by multiplying the average jet fuel price each year by 5,000 and 10,000 gallons. Because fuel prices fluctuated from \$1.70/gallon to \$3.11/gallon, the fuel cost fluctuates from $\$ 8,765$ to $\$ 15,815$ for 5,000 gallons and $\$ 17,530$ to $\$ 31,630$ for 10,000 gallons each flight. By keeping the carbon credit cost the same, it is easier to see that fuel cost per gallon far exceeds the carbon credit cost at 2013 prices. For instance, the jet fuel cost is $\$ 15,550$ for 5,000 gallons of fuel in 2012, and the cost of the credits for 5,000 gallons of fuel is $\$ 265$. Therefore, the impact of the fuel cost is far greater than the carbon credit cost at these price levels. Table 9 uses the same methodology as in Table 6, a $3 \%$ to $5 \%$ fuel reduction analysis with current prices and a fuel consumption of 5,000 gallons. Figure 2 is a graphical depiction of the payback period information presented in Table 9. As expected, the greater the reduction in fuel consumption, the lower the payback period. The longest payback period presented is for the year 2009 because that is the year with the lowest average fuel price in this study. The shorter payback periods presented for the years 2012, 2011 and 2008 reflect the higher prices of the fuel in those years. 
Table 7

Round Trip Cost Including 5,000 Gallons of Jet Fuel and Allowances

\begin{tabular}{cccc} 
Year & Jet Fuel Price per Gallon $^{\mathrm{a}}$ & Total Jet Fuel Cost & Total Round Trip Cost \\
\hline 2012 & $\$ 3.11$ & $\$ 15,550$ & $\$ 15,815$ \\
2011 & $\$ 3.05$ & $\$ 15,250$ & $\$ 15,515$ \\
2010 & $\$ 2.20$ & $\$ 11,000$ & $\$ 11,265$ \\
2009 & $\$ 1.70$ & $\$ 8,500$ & $\$ 8,765$ \\
2008 & $\$ 3.02$ & $\$ 15,100$ & $\$ 15,365$ \\
\hline
\end{tabular}

Note. ${ }^{\mathrm{a}}$ U.S. Energy Information Administration (2013). Jet Fuel Price per Gallon is average per year. Total Round Trip Cost includes Allowance and Gasoline Expenses.

Table 8

Round Trip Cost Including 10,000 Gallons of Jet Fuel and Allowances

\begin{tabular}{cccc} 
Year & Jet Fuel Price per Gallon & Total Jet Fuel Cost & Total Round Trip Cost \\
\hline 2012 & $\$ 3.11$ & $\$ 31,100$ & $\$ 31,630$ \\
2011 & $\$ 3.05$ & $\$ 30,500$ & $\$ 31,030$ \\
2010 & $\$ 2.20$ & $\$ 22,000$ & $\$ 22,530$ \\
2009 & $\$ 1.70$ & $\$ 17,000$ & $\$ 17,530$ \\
2008 & $\$ 3.02$ & $\$ 30,200$ & $\$ 30,730$ \\
\hline
\end{tabular}

Note. ${ }^{\text {a}}$ U.S. Energy Information Administration (2013). Jet Fuel Price per Gallon is average per year. Total Round Trip Cost includes Allowance and Gasoline Expenses. 
Table 9

One Million US Dollars Investment to Reduce Fuel Consumption Analysis Using 10,000 gallons per Roundtrip Flight

\begin{tabular}{|c|c|c|c|c|c|}
\hline Year & 2012 & 2011 & 2010 & 2009 & 2008 \\
\hline Total Trip Cost & $\$ 31,630$ & $\$ 31,030$ & $\$ 22,530$ & $\$ 17,530$ & $\$ 30,730$ \\
\hline Fuel Reduction & $3 \%$ & $3 \%$ & $3 \%$ & $3 \%$ & $3 \%$ \\
\hline Savings & $\$ 949$ & $\$ 931$ & $\$ 676$ & $\$ 526$ & $\$ 922$ \\
\hline Roundtrips to Payback & 1,054 & 1,074 & 1,479 & 1,901 & 1,085 \\
\hline Payback in Years & 0.7 & 0.7 & 1.0 & 1.3 & 0.7 \\
\hline Total Trip Cost & $\$ 31,630$ & $\$ 31,030$ & $\$ 22,530$ & $\$ 17,530$ & $\$ 30,730$ \\
\hline Fuel Reduction & $4 \%$ & $4 \%$ & $4 \%$ & $4 \%$ & $4 \%$ \\
\hline Savings & $\$ 1,265$ & $\$ 1,241$ & $\$ 901$ & $\$ 701$ & $\$ 1,229$ \\
\hline Roundtrips to Payback & 790 & 806 & 1,110 & 1,426 & 814 \\
\hline Payback in Years & 0.5 & 0.6 & 0.8 & 1.0 & 0.6 \\
\hline Total Trip Cost & $\$ 31,630$ & $\$ 31,030$ & $\$ 22,530$ & $\$ 17,530$ & $\$ 30,730$ \\
\hline Fuel Reduction & $5 \%$ & $5 \%$ & $5 \%$ & $5 \%$ & $5 \%$ \\
\hline Savings & $\$ 1,582$ & $\$ 1,552$ & $\$ 1,127$ & $\$ 877$ & $\$ 1,537$ \\
\hline Roundtrips to Payback & 632 & 645 & 888 & 1,141 & 651 \\
\hline Payback in Years & 0.4 & 0.4 & 0.6 & 0.8 & 0.4 \\
\hline
\end{tabular}

Note. Payback in years is calculated using an average of round trips per year estimate of 1,460 . Payback is calculated using savings. 


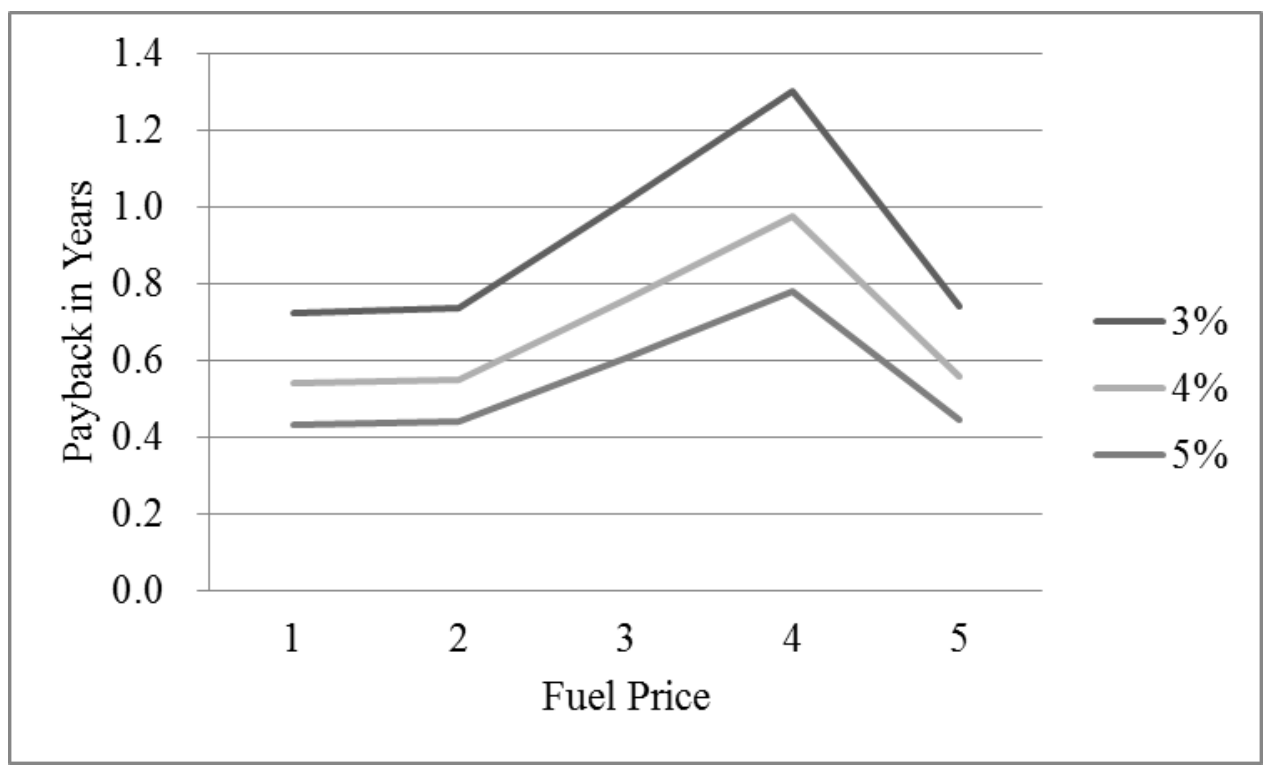

Figure 2. Comparison of payback using actual average fuel prices.

\section{Conclusion and Suggestions for Future Research}

Based on this analysis, investments to reduce fuel consumption are more effective when fuel prices are high. At current prices for carbon credits and fuel prices, the cost of emissions does not contribute to the savings as greatly as fuel savings does. If the carbon credit price increases dramatically, the contribution of carbon credits to reduce payback period will increase. The amount of fuel consumed drives these analyses such that price per gallon of fuel is added to the carbon credit cost per gallon. The percentage of fuel saved dramatically impacts the payback due to the cost of fuel being much higher than the cost per carbon credit. These investments may be either capital investments or operational expenses as the methodology does not consider cost of capital, depreciation, or tax benefits of investments.

The number of governing bodies that track and impose carbon regulations is expected to increase in the next decade as aviation organizations seek a global approach to the environmental impacts of aviation. Commercial aviation $\mathrm{CO}_{2}$ emissions are currently adding imposed costs to flights within the European Union. The stated purpose of the EU ETS is to reduce carbon emissions. A very effective way to reduce emissions is to reduce fuel consumption, as the EU ETS uses fuel consumption as the variable in carbon emission estimates. Reducing fuel consumption provides a win-win situation by reducing fuel costs and carbon emissions; therefore, having positive effects on the bottom line and the environment. Changes to aircraft or procedural changes may be implemented to reduce demand for fuel by reducing consumption while still providing the same level of air service. Investing in reducing fuel consumption is not only important to comply with 
any emission trading scheme, but will also become a major factor for survival in a competitive market. Future research is planned to include taxes, depreciation, and flight comparisons using flight crew calculations to augment the ICAO fuel consumption estimates. 


\section{References}

Adler, N. \& Gellman, A. (2012). Strategies for managing risk in a changing aviation environment. Journal of Air Transport Management, 21, 24-35.

Air Transport Action Group (ATAG). (2012). A sustainable flight path towards reducing emissions. http://www.atag.org/component/downloads/downloads/203.html

Air Transport Action Group (ATAG). (2013). Climate change. Retrieved from http://www.atag.org/our-activities/climate-change.html

Airlines for America (A4A). (2013). Energy \& environment. Retrieved from http://www.airlines.org/Pages/Energy_Environment.aspx

European Aviation Safety Agency (EASA). (2013). Aviation's environmental challenges. Retrieved from https:/www.easa.europa.eu/environment/environmentalchallenges.php

Federal Aviation Administration (FAA). (2012). Federal Aviation Administration policy, international affairs, and environment fiscal year 2013 business plan. Retrieved from http://www.faa.gov/about/plans_reports/media/2013/APL_FY2013_BusinessPlan_12-12-10.pdf

Federal Aviation Administration (FAA). (2012a). FAA destination 2025. Retrieved fromhttp://www.faa.gov/about/plans_reports/media/Destination2025.pdf

Federal Aviation Administration (FAA). (2012b). NextGen and the environment. Retrieved from http://www.faa.gov/nextgen/media/ nextgenAndTheEnvironment.pdf

Fonta, P. (2010b). ICAO Environmental Report 2010. Chapter 2, Aircraft technology improvements Retrieved from http://legacy.icao.int/icao/en/env2010/Pubs/EnvReport2010/ICAO_EnvReport10Ch2_en.pdf

Hupe, J. (2010). “Assembly resolution on international aviation and climate change (A37-19)”. Introduction to ICAO environmental activities. ICAO environmental report 2010. Retrieved from http://legacy.icao.int/icao/en/env2010/Pubs/EnvReport2010/ICAO_EnvReport10Intro_en.pdf 
International Air Transport Association (IATA). (2009). A global approach to reducing aviation emissions. Retrieved from http://www.iata.org/SiteCollectionDocuments/Documents/Global_Approach_Reduc ing_Emissions_251109web.pdf

International Air Transport Association (IATA). (2013). Climate change. Retrieved from http://www.iata.org/policy/environment/Pages/climate-change.aspx

International Civil Aviation Organization (ICAOa). (2013). Joint statement of ICAO and ATAG to cooperate on the promotion of sustainable approaches to global aviation emissions reduction. Retrieved from http://www.icao.int/Newsroom/News\%20Doc\%202013/Joint\%20Statement_ICAOATAG_US-Letter_2013-05-13_signed.pdf

International Civil Aviation Organization (ICAOb). (2013). Environmental protection. Retrieved from http://www.icao.int/environmental-protection/Pages/default.aspx

International Civil Aviation Organization Secretariat. (2010). ICAO environmental report 2010. Introduction: aviation outlook. Retrieved from http://legacy.icao.int/icao/en/env2010/Pubs/EnvReport2010/ICAO_EnvReport10Outlook_en.pdf

International Civil Aviation Organization Secretariat. (2010a). ICAO environmental report 2010. Chapter 1, Aviation's Contribution to Climate Change. Retrieved from http://legacy.icao.int/icao/en/env2010/Pubs/EnvReport2010/ICAO_EnvReport10Ch1_en.pdf

International Civil Aviation Organization Secretariat. (2010b). ICAO environmental report 2010. Chapter 2, Aircraft technology improvements. Retrieved from http://legacy.icao.int/icao/en/env2010/Pubs/EnvReport2010/ICAO_EnvReport10Ch2_en.pdf

International Civil Aviation Organization Secretariat. (2010c). ICAO environmental report 2010. Chapter 3, operational opportunities. Retrieved from http://legacy.icao.int/icao/en/env2010/Pubs/EnvReport2010/ICAO_EnvReport10Ch3_en.pdf

International Civil Aviation Organization Secretariat. (2010d). ICAO environmental report 2010. Chapter 4, Economic instruments. Retrieved from http://legacy.icao.int/icao/en/env2010/Pubs/EnvReport2010/ICAO_EnvReport10Ch4_en.pdf 
International Civil Aviation Organization Secretariat. (2010e). ICAO environmental report 2010. Chapter 6, Adaptation. Retrieved from http://legacy.icao.int/icao/en/env2010/Pubs/EnvReport2010/ICAO_EnvReport10Ch6_en.pdf

International Civil Aviation Organization. (2010f). Focus on the environment. Retrieved from http://legacy.icao.int/icao/en/Env2010/Pubs/ICAO_EnvBrochure_en.pdf

Intergovernmental Panel on Climate Change (IPCC). (2007). IPCC fourth assessment report: climate change 2007. Retrieved from http://www.ipcc.ch/publications_and_data/ar4/syr/en/mains1.html

Johnson, M., Gonzalez, A., Kozak, B, \& Sperlak, L. (2013). Carbon estimation and offsets for U.S. university aviation programs. Collegiate Aviation Review, 31(1), 40-56.

Kråkenes, T., Keldusild, K. (2010). ICAO environmental report 2010. Chapter 4, Economic instruments. Retrieved from http://legacy.icao.int/icao/en/env2010/Pubs/EnvReport2010/ICAO_EnvReport10Ch4_en.pdf

Krammer, P., Dray, L., Kohler, M. (2013). Climate-neutrality versus carbon-neutrality for aviation biofuel policy. Transportation Research Part D, 23, 64-72.

Lee, D., Fahey, D., Forster, P., Newton, P., Wit, R. \& Lim, L. (2009). Aviation and global climate change in the 21st century. Atmospheric Environment, 43(22), 35203537.

Meltzer, J. (2012). Climate Change and Trade-The EU Aviation Directive and the WTO. Journal of International Economic Law, 15(1), 111-156.

Sgouridis, S.; Bonnefoy, P. \& Hansman, R. (2011). Air transportation in a carbon constrained world: Long-term dynamics of policies and strategies for mitigating the carbon footprint of commercial aviation. Transportation Research Part A, 2011, 45(10), 1077-1091.

Shimizu, T. (2010). Chapter 4, Economic instruments. ICAO environmental report 2010 Retrieved from http://legacy.icao.int/icao/en/env2010/Pubs/EnvReport2010/ICAO_EnvReport10Ch4_en.pdf 
Steele, P. (2010). Chapter 4, Economic Instruments. ICAO environmental report 2010 Retrieved from http://legacy.icao.int/icao/en/env2010/Pubs/EnvReport2010/ICAO_EnvReport10Ch4_en.pdf

U.S. Energy Information Administration (EIA). (2013). U.S. kerosene-type jet fuel retail sales by refiners. Retrieved from http://www.eia.gov/dnav/pet/hist/LeafHandler.ashx?n=PET\&s=EMA_EPJK_PTG_ NUS_DPG\&f=M

United States Government (USG). (2012). U.S. aviation greenhouse gas emissions reduction plan submitted to the International Civil Aviation Organization, June 2012. Retrieved from

http://www.faa.gov/about/office_org/headquarters_offices/apl/environ_policy_guid ance/policy/media/Aviation_Greenhouse_Gas_Emissions_Reduction_Plan.pdf 